\title{
PENGARUH SINETRON REMAJA DI TELEVISI SWASTA TERHADAP SIKAP MENGENAI GAYA HIDUP HEDONIS
}

\author{
C. Suprapti Dwi Takariani \\ Balai Pengkajian dan Pengembangan Komunikasi dan Informatika (BPPKI) Bandung \\ Jalan Pajajaran No.88 Bandung, Jawa Barat - 40173 Telp.(022) 6017493 Fax. (022)6021740, HP. 08122179515 , \\ email :dwi.takariani@gmail.com \\ Naskah diterima tanggal 30 April 2013, disetujui pada tanggal 24 Juni 2013
}

\section{THE INFLUENCE OF TEENS SINETRONS ON PRIVATE TELEVISION AGAINST ATTITUDES ABOUT HEDONISTIC LIFESTYLE}

\begin{abstract}
Sinetrons are now almost dominated private television program. Most of the story contains glamorous and luxurious teenage lifestyle. The objective is to analyze the influence of the intensity of watching, attractiveness, and messages content of television's sinetrons. This study used Explanatory Survey Method. The population in this study are students of SMA Negeri 4 Cimahi, West Java Province. Sampling technique used Stratified Proportional Random Sampling. Result showed teen sinetron affect significantly to the attitude of the hedonistic lifestyle.
\end{abstract}

Keywords : teen sinetrons, television, attitudes about hedonistic lifestyle.

\begin{abstract}
Abstrak
Tayangan sinetron saat ini hampir mendominasi program acara di televisi swasta. Tema-tema ceritanya sebagian besar berisi gaya hidup remaja yang glamor dan kemewahan.Tujuan penelitian ini adalah untuk menganalisis besarnya pengaruh intensitas menonton, daya tarik, dan isi pesan tayangan sinetron remaja di televisi swasta terhadap sikap mengenai gaya hidup hedonis. Penelitian ini menggunakan metode survei penjelasan (Explanatory Survey Method). Populasi dalam penelitian ini adalah siswa SMA Negeri 4 Cimahi, Provinsi Jawa Barat. Teknik sampling yang digunakan adalah Stratified Proportional Random Sampling. Hasil penelitian menunjukkan bahwa tayangan sinetron remaja di televisi swasta berpengaruh secara signifikan terhadap sikap mengenai gaya hidup hedonis.
\end{abstract}

Kata kunci : sinetron remaja, televisi, sikap mengenai gaya hidup hedonis.

\section{PENDAHULUAN}

Perkembangan pertelevisian di Indonesia ditandai dengan hadirnya beberapa stasiun televisi swasta. Kurang lebih ada 11 stasiun televisi swasta yang bersiaran di tanah air, belum lagi televisi-televisi lokal yang bertebaran di daerah-daerah. Di satu sisi, perkembangan tersebut sangat membanggakan karena berarti teknologi di Indonesia berkembang. Namun, di sisi lain, berkaitan dengan program-program acaranya, banyak acara yang ditayangkan kurang memberikan unsur pendidikan bagi pemirsanya.

Tak dapat dipungkiri, media televisi saat ini banyak menyedot perhatian pemirsa. 
Data dari Lembaga Survei Nielson yang memaparkan jumlah penonton sepanjang kuartal pertama tahun 2011 untuk semua stasiun televisi di 10 kota besar di Indonesia naik sebesar $11,47 \%$ atau naik menjadi 6,8 juta penonton dibandingkan pada kuartal pertama tahun 2010 di mana jumlah penonton televisi sebanyak 6,1 juta penonton (Evilin, 2011).

Dari sekian banyak program acara yang disuguhkan di televisi, acara sinetron menjadi acara yang banyak digemari penonton, mulai dari anak-anak hingga orang dewasa karena, memang ada banyak sinetron yang dibuat untuk berbagai segmen. Rinawati (2009) menyebutkan bahwa sinetron merupakan singkatan dari sinema elektronik yang pada dasarnya sama dengan film. Bedanya, sinetron merupakan cerita yang berlanjut atau bersambung dan diambil dengan kamera video (secara elektronik). Saat ini tayangan sinetron banyak menghiasi stasiun televisi di Indonesia. Hampir semua stasiun televisi berlomba-lomba untuk memproduksi sinetron. Faktor yang mendorong lakunya permintaan terhadap tayangan sinetron di antaranya adalah daya tarik cerita dan tokoh cerita. Sinetron-sinetron yang ditayangkan stasiun televisi banyak menampilkan ceritacerita dengan tema kehidupan remaja dan dimainkan artis-artis remaja pula. Sebagai contoh, sinetron dengan judul "Tebe dan Kakak Cantik", "Hati-hati dengan Hati", yang disiarkan di Indosiar. Kemudian RCTI menyiarkan sinetron "Candy", "Magic", "Cinta 7 Susun". SCTV menyiarkan sinetron "Putih Abu-Abu seri 1 dan 2", kemudian Global TV menampilkan sinetron remaja "Kinara". Sinetron-sinetron tersebut kebanyakan ditayangkan pada primetime atau jam tayang utama.

Tema cerita dari sinetron-sinetron tersebut hampir semuanya menampilkan adegan-adegan kekerasan baik kekerasan verbal maupun nonverbal, seperti menampar, mengeluarkan kata-kata kasar, seronok, adegan-adegan yang kurang hormat kepada orang yang sudah tua. Selain itu sinetron remaja di televisi banyak menampilkan cerita mengenai remaja dari kalangan kelas atas dan mempunyai konflik utama yang hampir sama, yakni problema cinta.

Tema cerita yang menggambarkan gaya hidup mewah dalam sinetron tersebut dikhawatirkan akan memengaruhi perilaku remaja terutama perilaku konsumtif yang nantinya akan berpengaruh pada gaya hidup remaja seperti gaya hidup hedonis dan gaya hidup serba instan. Kekuatan media sering menciptakan imitasi di kalangan masyarakat, mulai dari anak-anak hingga orang dewasa, termasuk remaja. Perilaku para pemeran sinetron tidak jarang ditiru oleh penontonnya. Mereka mengubah model rambut dan dandannya serta gaya hidup dan bahasa seperti pemain dalam sinetron.

Gaya hidup hedonis saat ini sudah merambah tidak hanya pada remaja di perkotaan. Remaja di daerah pinggiran pun sudah mulai mengikuti gaya hidup hedonis, di mana orientasi hidup selalu diarahkan pada kenikmatan dan kesenangan. Remaja yang merupakan peralihan dari anak ke dewasa, masih mencari jati diri dan jiwanya masih labil sehingga mudah dipengaruhi oleh halhal yang menurut mereka baru, dan mereka tidak akan segan-segan untuk meniru hal-hal tersebut meskipun sebenarnya kurang pantas. Tayangan sinetron di televisi yang ceritanya memberikan gambaran kenikmatan dan kesenangan, mimpi-mimpi, dan semakin jauh dari realitas telah menyihir penontonnya. Secara tidak sadar, para penonton telah tergiring untuk meniru gaya hidup yang disajikan para pemain sinetron. Dari uraian latar belakang penelitian tersebut, maka penulis tertarik untuk melakukan penelitian dengan judul pengaruh tayangan sinetron remaja di televisi swasta terhadap sikap mengenai gaya hidup hedonis.

Adapun identifikasi masalahnya adalah: 1) Seberapa besar pengaruh intensitas menonton tayangan sinetron remaja di televisi swasta terhadap sikap mengenai gaya hidup hedonis?; 2) Seberapa besar pengaruh daya tarik sinetron remaja di televisi swasta terhadap sikap mengenai gaya hidup hedonis?; 3) Seberapa besar pengaruh isi pesan sinetron remaja di televisi swasta terhadap sikap mengenai gaya hidup hedonis?

Tujuan penelitian ini adalah: 1) untuk menganalisis seberapa besar pengaruh 
intensitas menonton tayangan sinetron remaja di televisi swasta terhadap sikap mengenai gaya hidup hedonis; 2) untuk menganalisis seberapa besar pengaruh daya tarik sinetron remaja di televisi swasta terhadap sikap mengenai gaya hidup hedonis; 3) untuk menganalisis seberapa besar pengaruh isi pesan sinetron remaja di televisi swasta terhadap sikap mengenai gaya hidup hedonis.

Manfaat penelitian ini adalah memberi masukan kepada para pengelola stasiun televisi swasta agar memerhatikan programprogram acara yang ditayangkannya, khususnya tayangan sinetron, karena banyak tayangan sinetron yang isinya tidak memberikan pendidikan yang baik kepada pemirsanya. Pengelola stasiun televisi agar menyesuaikan dengan jam tayang untuk anak, remaja, dan khusus orang dewasa.

Memberi masukan kepada Dirjen Informasi dan Komunikasi Publik dalam hal ini Direktorat Pengelolaan Media Publik Kementerian Kominfo, agar selalu memantau perkembangan pertelevisian di Indonesia, dan mengupayakan dukungan penyampaian pesan-pesan edukasi dari program-program di televisi khususnya pada program acara hiburan seperti sinetron kepada masyarakat.

Memberi masukan kepada KPI untuk selalu mengawasi program-program acara di televisi khususnya tayangan sinetron agar program-program tersebut disesuaikan dengan budaya bangsa Indonesia dan tayangan-tayangan yang tidak sesuai dengan budaya Indonesia dikurangi atau dihapus sama sekali serta menegur stasiun televisi yang melanggar aturan.

\section{LANDASAN KONSEP}

\section{Media Televisi}

Siaran televisi di Indonesia secara resmi dimulai pada tahun 1962. Selama 27 tahun penonton televisi di Indonesia hanya dapat menonton satu saluran televisi. Baru pada tahun 1989, pemerintah memberikan izin operasi kepada kelompok usaha Bimantara untuk membuka stasiun televisi RCTI yang merupakan televisi swasta pertama di
Indonesia, disusul kemudian dengan SCTV, Indosiar, ANTV, dan TPI. Gerakan reformasi pada tahun 1998 telah memicu perkembangan industri media massa khususnya televisi. Menjelang tahun 2000 muncul lima stasiun televisi baru, yakni Metro TV, Trans TV, TV7, Lativi, dan Global, serta beberapa stasiun televisi daerah yang saat ini jumlahnya mencapai puluhan stasiun televisi lokal (Morissan, 2009).

Televisi merupakan sistem elektronik yang mengirimkan gambar diam dan gambar hidup bersama suara melalui kabel atau ruang. Sistem ini menggunakan peralatan yang mengubah cahaya dan suara ke dalam gelombang elektronik dan mengonversinya kembali ke dalam cahaya yang dapat dilihat dan suaranya dapat didengar (Effendy, 2003). Selanjutnya dikatakan bahwa televisi juga dapat diartikan sebagai kotak televisi, rangkaian televisi atau pancaran televisi. Kata "televisi" merupakan gabungan dari kata tele (jauh) dari bahasa Yunani dan visio (penglihatan) dari bahasa Latin. Sehingga televisi dapat diartikan sebagai telekomunikasi yang dapat dilihat dari jarak jauh.

Dengan menonton televisi, audience dapat melihat gambar yang lebih jelas daripada media massa lainnya. Daya tarik ini selain melebihi radio juga melebihi film bioskop, karena dengan menonton televisi, program acara dapat dinikmati di rumah dengan aman dan nyaman (Effendy, 2003).

Mulyana (2001) mengatakan dewasa ini, televisi boleh dikatakan telah mendominasi hampir semua waktu luang setiap orang. Televisi memiliki sejumlah kelebihan, terutama kemampuannya dalam menyatukan antara fungsi audio dan fungsi visual, ditambah dengan kemampuannya dalam memainkan warna. Selain itu, televisi juga mampu mengatasi jarak dan waktu, sehingga penonton yang tinggal di daerah terpencil dapat menikmati siaran televisi.

Sebagai media elektronik, televisi memiliki ciri-ciri, seperti yang disebutkan Effendy (2003), yakni berlangsung satu arah, komunikatornya melembaga, pesannya bersifat umum, sasarannya menimbulkan keserempakan dan komunikannya heterogen. 


\section{Sinetron di Televisi}

Istilah sinetron pertama kali diperkenalkan oleh Soemardjono, salah satu pendiri Institut Kesenian Jakarta (IKJ). Dalam bahasa Inggris sinetron biasa disebut dengan soap opera atau opera sabun. Menurut Garin Nugroho, istilah opera sabun timbul saat drama serial mengalami masa booming di dunia pertelevisian Amerika. Drama-drama tersebut banyak menyedot perusahaanperusahaan yang memproduksi sabun untuk memasang iklan. Maka, disebutlah drama ini sebagai opera sabun (Anonim, 2011). Sinetron yang pertama kali muncul di Indonesia berjudul 'Losmen' yang ditayangkan sekitar tahun 80an oleh TVRI, stasiun televisi milik pemerintah Indonesia, sekaligus satu-satunya televisi yang ada saat itu. Sinetron kemudian berkembang dengan tema yang beragam seiring dengan perkembangan jumlah stasiun televisi swasta di Indonesia.

Perkembangan sinetron di tanah air saat ini cukup pesat sejalan dengan perkembangan stasiun televisi itu sendiri. Hampir semua stasiun televisi saat ini menayangkan sinetron dengan tema yang hampir sama. Sinetron remaja tampaknya paling banyak mendominasi stasiun televisi.

Secara umum, hampir sebagian besar slot waktu stasiun TV didominasi oleh sinetron. Mulai dari primetime atau waktu yang menjadi waktu utama hingga pagi hari ketika aktivitas luar rumah tinggi. Waktu utama tayangan televisi pun semakin lebar. Jika beberapa tahun yang lalu waktu utama siaran televisi sekitar pukul 19.00 s.d 21.00 tetapi sekarang menjadi 18.00 s.d 23.00. Seperti yang dikutip dari ungkapan Marketing and Communication Execuitve AGB Nielsen, Andini dalam Yagami (2011), indikasi utama adalah acara-acara yang memiliki rating tinggi berada di waktu utama tersebut. Sebuah stasiun televisi swasta nasional ada yang memiliki slot waktu tayang sinetron dalam sehari mencapai 7 jam. Waktu penayangannya pun berada di waktu utama, yakni pukul 18.00 s.d 22.00 malam. Jika didefinisikan waktu utama sebagai waktu potensi paling besar pemirsa menyaksikan tayangan, maka demikian tinggi penghargaan terhadap sinetron.

\section{Sikap Remaja dan Gaya Hidup Hedonis}

Tidak dapat dipungkiri bahwa tayangan sinetron tersebut akan memberikan pengaruh baik atau buruk bagi penontonnya. Seperti dikatakan Mar'at dalam Effendy (1986) bahwa acara televisi pada umumnya memengaruhi sikap, pandangan, persepsi, dan perasaan penonton. Sikap, menurut Azwar (2005), adalah suatu bentuk evaluasi/reaksi terhadap suatu objek, memihak/tidak memihak yang merupakan keteraturan tertentu dalam hal perasaan (afeksi), pemikiran (kognisi), dan predisposisi tindakan (konasi) seseorang terhadap suatu aspek di lingkungan sekitarnya. Adapun komponen sikap terdiri dari aspek kognitif, afektif, dan konatif. Aspek kognitif terbentuk dari pengetahuan dan informasi yang diterima yang selanjutnya diproses menghasilkan suatu keputusan untuk bertindak. Aspek afektif menyangkut masalah emosional subjektif sosial terhadap suatu objek. Secara umum komponen ini disamakan dengan perasaan yang dimiliki terhadap suatu objek. Aspek konatif menunjukkan bagaimana perilaku atau kecenderungan berperilaku yang ada dalam diri seseorang berkaitan dengan objek sikap yang dihadapinya.

Remaja merupakan salah satu segmen penonton yang menyukai sinetron yang ditayangkan di televisi. Tayangan sinetron di televisi khususnya televisi swasta tampaknya telah mengubah pola kehidupan remaja. Banyak aktivitas yang ditinggalkan hanya sekadar agar tidak tertinggal menyaksikan sinetron di televisi kesayangannya.

Media massa menjadi salah satu faktor dalam pembentukan sikap remaja. Televisi sebagai salah satu media massa, mempunyai kelebihan dibandingkan dengan media massa lain, karena televisi secara audio visual menghadirkan gambar secara hidup sehingga penonton seolah-olah hadir dalam peristiwa yang disajikan. Dengan kelebihannya tersebut televisi dapat menimbulkan pengaruh terhadap khalayaknya. Seperti terlihat dalam 
tayangan sinetron yang bertemakan remaja, isi ceritanya menampilkan gaya hidup remaja metropolis yang cenderung kearah gaya hidup hedonis.

Menurut Munandar (2012) gaya hidup menggambarkan keseluruhan diri seseorang yang berinteraksi dengan lingkungannya, gaya hidup adalah perpaduan antara kebutuhan ekspresi diri dan harapan kelompok terhadap seseorang dalam bertindak berdasarkan pada norma yang berlaku. Sementara itu gaya hidup hedonis adalah suatu pola hidup yang aktivitasnya untuk mencari kesenangan hidup, seperti lebih banyak menghabiskan waktu di luar rumah, lebih banyak bermain, senang pada keramaian kota, senang membeli barang mahal, serta selalu ingin menjadi pusat perhatian.

Kata hedone sendiri berasal dari bahasa Yunani yang berarti kesenangan atau kenikmatan. Hedonisme adalah pandangan hidup yang menganggap bahwa kesenangan dan kenikmatan materi adalah tujuan utama hidup. Bagi para penganut paham ini, bersenang-senang, pesta-pora, dan pelesiran merupakan tujuan utama hidup, entah itu menyenangkan bagi orang lain atau tidak. Mereka beranggapan hidup ini hanya sekali, sehingga mereka merasa ingin menikmati hidup senikmat-nikmatnya. Di dalam lingkungan penganut paham ini, hidup dijalani dengan sebebas-bebasnya demi memenuhi hawa nafsu yang tanpa batas. Pengertian hedonisme disampaikan beberapa filsuf Yunani yang menyatakan bahwa manusia dari kodratnya mencari kesenangan, bahwa perasaan-perasaan senang adalah baik dan perasaan-perasaan sedih adalah jelek. Hedonisme menyatakan bahwa tujuan hidup adalah kebahagiaan atau mencapai kesenangan sebanyak mungkin (sebesarbesarnya) dengan jerih payah sesedikit mungkin (sekecil-kecilnya) (Brahm, 2003).

Banyak faktor yang memengaruhi gaya hidup hedonisme, yakni faktor internal dan eksternal. Faktor internal misalnya adalah lingkungan sekolah, keluarga, dan pergaulan. Sementara faktor eksternal antara lain adalah tayangan televisi.

Dari sekian banyak tayangan televisi, acara sinetron tampaknya yang paling banyak menampilkan gaya hidup hedonis. Tayangan-tayangan sinetron remaja di televisi banyak mengangkat tema-tema gaya hidup hedonis, memperlihatkan perilaku hidup mewah dan bersenang-senang dari para pemainnya, ceritanya banyak yang tidak sesuai dengan budaya Indonesia. Meskipun perilaku tersebut kurang baik, namun sampai saat ini sinetron yang berisi cerita mengenai hal itu masih terus diproduksi karena memang disukai oleh penontonnya (Dyah, 2012).

\section{Kerangka Pemikiran}

Teori yang akan dipakai dalam penelitian ini adalah Teori Belajar Sosial (Social Learning Theory) dari Bandura. Terjadi banyak pembelajaran seseorang melalui pengamatan pada perilaku orang lain. Permulaan proses belajar ialah munculnya peristiwa yang dapat diamati secara langsung atau tidak langsung oleh seseorang. Menurut Bandura, kita belajar bukan saja dari pengalaman langsung, tetapi dari peniruan atau peneladanan (modeling) (Rakhmat, 1998). Perilaku merupakan faktor-faktor kognitif dan lingkungan. Peristiwa ini dapat berupa tindakan tertentu atau gambaran pola pemikiran, yang disebut sebagai abstract modeling. Teori ini juga mengakui bahwa manusia mampu menyadari atau berpikir dan bahwa mereka dapat mengambil manfaat dari pengamatan dan pengalaman. Selanjutnya dikatakan bahwa banyak pembelajaran manusia terjadi dengan menyaksikan orang lain yang menampilkan perilaku yang beraneka ragam. Misalnya seorang murid balet dapat mempelajari gerakan-gerakan tertentu dengan menyaksikan instruktur yang mendemonstrasikan gerakan-gerakan itu. Jenis pembelajaran ini juga dapat dengan jelas terjadi melalui media massa (Severin dan Tankard, 2007).

Menurut Tan (1981), media massa memainkan peran yang penting sebab manusia memiliki keterbatasan untuk mengalami peristiwa secara langsung. Banyak dari apa yang dipelajarinya diamati melalui media massa, terutama media visual. Media massa dapat memperluas cakupan apa yang 
dapat individu pelajari dengan menerpanya untuk meniru peristiwa di mana ia tidak memiliki kontak langsung dengan peristiwa itu. Selanjutnya, dikatakan oleh Bandura, proses belajar sosial dibagi dalam empat tahapan proses: proses perhatian, proses pengingatan (retention), proses reproduksi motoris, dan proses motivasional. Tan (1981) mengatakan, peristiwa ini dapat berupa tindakan tertentu atau gambaran pola pemikiran, yang disebut Bandura sebagai abstract modeling. Seseorang mengamati peristiwa tersebut dari orang-orang yang berada di sekelilingnya atau sajian televisi. Bila peristiwa itu sudah diamati, terjadilah tahap pertama belajar sosial yakni perhatian. Seseorang baru dapat mempelajari sesuatu bila ia memperhatikannya.

Perhatian pada suatu peristiwa, dalam perspektif teori ini, ditentukan oleh karakteristik peristiwa (modeling stlimuli), dan karakteristik yang mengamatinya. Kesempatan untuk belajar dari satu peristiwa menjadi lebih luas disebabkan oleh pengamatan terhadap peristiwa itu yang berulang-ulang. Dijelaskan oleh Bandura, seorang anak yang jarang sekali menonton televisi, tak mungkin belajar perilaku agresif yang dilihatnya di televisi. Karakteristik yang ada pada diri pengamat juga memengaruhi perhatian. Kapasitas seseorang untuk memperoleh informasi, menentukan sebaik apa dia akan dapat belajar dari peristiwa yang diamati.

Pada proses pengingatan (retention) berhubungan dengan kesanggupan khalayak menyimpan hasil pengamatannya dalam benaknya dan memanggilnya kembali tatkala mereka bertindak sesuai dengan teladan yang diberikan. Peneladanan tertangguh (delayed modeling) hanya terjadi bila mereka sanggup mengingat peristiwa yang diamatinya. Seorang remaja akan mampu mencontoh gaya hidup remaja di tayangan sinetron, bila ia dapat mengingat contoh yang dilakukan oleh model tersebut.

Dalam proses reproduksi motoris untuk mengingat, peristiwa yang diamati harus direkam dalam bentuk imaginal dan verbal. Bentuk imaginal disebut juga visual imagery, berarti membuat gambaran mental tentang peristiwa yang diamati dan menyimpan gambaran itu pada memori seseorang. Sedangkan bentuk verbal menunjukkan representasi peristiwa dalam bentuk bahasa. Menurut Bandura, agar peristiwa dapat diteladani, seseorang bukan saja harus merekamnya dalam bentuk memori, tetapi juga harus mampu membayangkannya secara mental bagaimana seseorang dapat menjalankan tindakan yang diteladaninya. Memvisualisasikan dirinya sedang melakukan sesuatu disebut sebagai rehearsial. Jarang sekali perilaku dapat direproduksi hanya dalam sekali pengamatan. Perilaku yang benar merupakan hasil uji coba. Dalam hal ini feedback memiliki peran untuk mengoreksi ketidaksesuaian perilaku hasil pengamatan dan perilaku model.

Pada proses motivasional berkaitan dengan kemungkinan menampilkan kembali perilaku yang telah diamati selain bergantung kepada kesempatan dan proses reproduksi motoris, bergantung juga kepada proses motivasional. Motif bergantung pula pada peneguhan (reinforcement). Menurut teori ini, ada tiga jenis peneguhan yang mendorong seseorang untuk bertindak ketiga peneguhan itu adalah peneguhan eksternal (external reinforcement), peneguhan wakilan (vicarious reinforcement), dan peneguhan diri (self reinforcement).

Pengaruh komunikasi massa terhadap khalayak terdiri dari tiga macam, pengaruh pertama, komunikasi massa akan memengaruhi kognisi khalayak yang berupa pengetahuan; kemudian pengaruh kedua adalah afeksi yang meliputi perasaan seseorang mengenai sesuatu; pengaruh ketiga adalah konasi yang meliputi kecenderungan atau keinginan bertindak dari seorang individu mengenai sesuatu (Rinawati, 2002).

Dengan merujuk pada pendapat Bandura tersebut, maka kerangka pemikiran penelitian ini tergambar pada gambar 1 . 


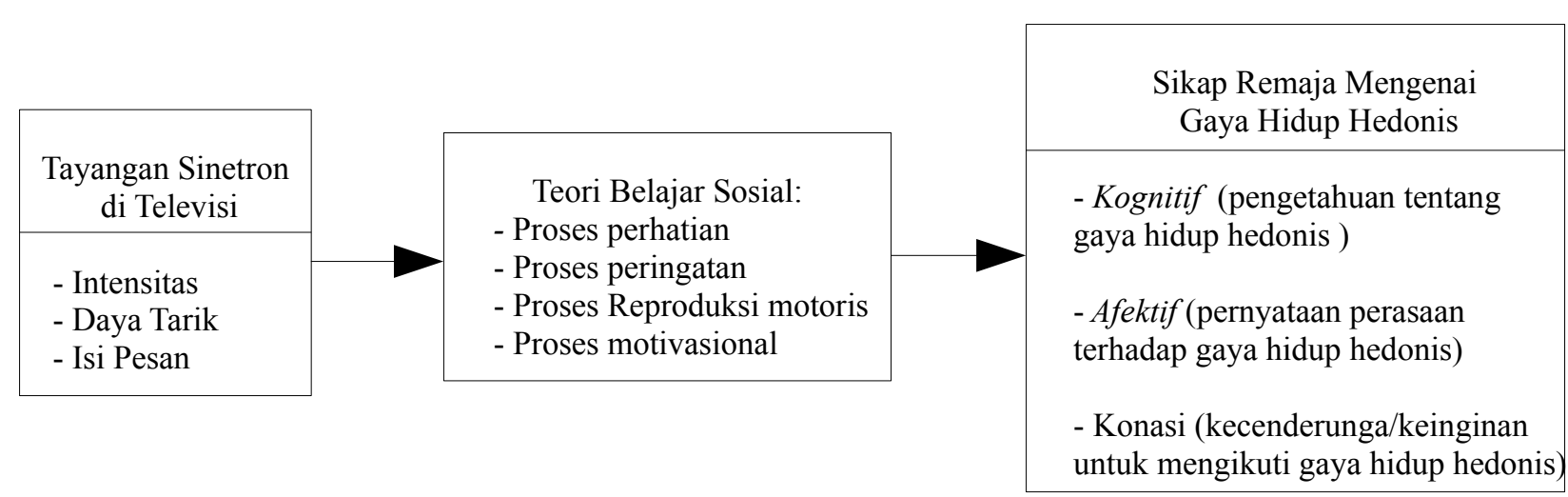

\section{Gambar 1}

Kerangka Pemikiran

\section{Hipotesis Penelitian}

Dari kerangka pemikiran tersebut, penulis mencoba membuat hipotesis sebagai berikut:

- Intensitas menonton tayangan sinteron remaja di televisi swasta berpengaruh terhadap sikap remaja mengenai gaya hidup hedonis.

- Daya tarik sinetron remaja di televisi swasta berpengaruh terhadap sikap remaja mengenai gaya hidup hedonis.

- Isi pesan sinetron remaja di televisi swasta berpengaruh terhadap sikap remaja mengenai gaya hidup hedonis.

\section{METODE PENELITIAN}

Penelitian ini menggunakan Metode Survei Penjelasan (Explanatory Survey Method) yaitu suatu penelitian penjelasan terhadap peristiwa atau keadaan (explanation). Penjelasan ini erat kaitannya dengan pertanyaan apa penyebab atau apa yang memengaruhi terjadinya suatu peristiwa atau keadaan dan akibat yang ditimbulkannya (Kriyantono, 2006).

Metode penelitian ini mengambil sampel dari suatu populasi dan menggunakan suatu kuesioner sebagai alat pokok dalam pengumpulan data (Singarimbun, 1989). Sifat penelitian adalah verifikasi dan deskriptif.

Populasi dalam penelitian ini adalah siswa yang berstatus remaja dan bersekolah di SMA Negeri 4 Cimahi, Provinsi Jawa Barat, kelas dua dan kelas tiga yang berjumlah 625 orang. Teknik sampling yang digunakan adalah Stratified Proporsional Random Sampling. Jumlah sampel secara menyeluruh ditetapkan berdasarkan rumus Taro Yamane (Rakhmat, 2007) sebagai berikut:

$$
\mathrm{n}=\frac{\mathrm{N}}{--------}
$$

Dimana :

$\mathrm{n}=$ sampel

$\mathrm{N}=$ populasi

$\mathrm{d}=$ presisi $10 \%$ dengan tingkat kepercayaan 95\% $(Z=2)$.

Diperoleh sampel sebanyak 86 orang. Jumlah sampel per kelas ditetapkan berdasarkan proporsi populasi dari masingmasing kelas, sebagai contoh populasi kelas 2 adalah sebesar $(325 / 625) \times 100 \%=52 \%$ jadi sampel dari kelas 2 sebanyak 52\% x $86=$ 44,72 dibulatkan menjadi 45. Jumlah sampel responden dapat dilihat pada Tabel 1. 


\section{Tabel 1}

Populasi dan Sampel Penelitian

\begin{tabular}{cccc}
\hline No. & Kelas & Populasi & Sampel \\
\hline 1. & Kelas 2 & 325 & 45 \\
2. & Kelas 3 & 300 & 41 \\
\hline & Jumlah : & 625 & 86 \\
\hline
\end{tabular}

Sumber: SMAN 4 Cimahi 2012

Operasionalisasi variabel-variabel bebas (X) dalam penelitian ini adalah tayangan sinetron remaja di televisi swasta yakni sinetron bertema remaja yang ditayangkan di stasiun televisi swasta, dengan subvariabel: (1) intensitas menonton dengan indikator: durasi menonton dan frekuensi menonton; (2) daya tarik sinetron dengan indikator: tema cerita, figur pemainnya, gaya bahasa; (3) Isi pesan dengan indikator: pesan moral, pesan etika dalam bergaul, pesan gaya hidup remaja. Variabel terikat $(\mathrm{Y})$ adalah sikap remaja yang diukur melalui aspek kognisi, afeksi, dan konasi.

Teknik pengumpulan datanya dilakukan dengan mengelompokkan data menjadi dua yaitu data primer dan sekunder. Data primer diperoleh dengan menggunakan angket yang disusun berdasarkan skala likert dengan kategori sangat setuju (SS) skor 5, setuju (S) skor 4, ragu-ragu (R) skor 3, tidak setuju (TS) skor 2, sangat tidak setuju skor (1). Data sekunder adalah data berupa dokumen, catatan, laporan dan lain sebagainya.

Teknik analisis datanya menggunakan analisis Regresi Linear Berganda. Uji validitas menggunakan formula hitung korelasi Pearson Product Moment, yang bertujuan untuk menjelaskan tingkat pengaruh di antara dua variabel yang memiliki gejala interval (Arikunto. 1998). Uji reliabilitas menggunakan metode Alpha Cronbach. Reliabilitas menunjukkan pada tingkat keandalan sesuatu. Reliabel artinya dapat dipercaya, jadi dapat diandalkan (Arikunto, 1998).

Dalam melaksanakan penelitian sebelumnya dilakukan pengujian alat ukur yaitu dengan uji validitas dan uji reliabilitas. Uji coba bertujuan untuk mengetahui apakah instrumen penelitian telah memenuhi persyaratan ditinjau dari kesahihan dan keterandalannya. Hasil tes instrumen mempunyai validitas yang tinggi apabila memberikan hasil ukur yang sesuai dengan maksud dilakukannya pengukuran (Saefudin, 1997).

Sebelum dilakukan pengujian hipotesis, terlebih dahulu dilakukan uji persyaratan analisis berupa uji normalitas dan uji homogenitas.

\section{HASIL PENELITIAN DAN PEMBAHASAN}

\section{Karakteristik Responden}

Jumlah sampel dalam penelitian ini adalah 86 orang, dari keseluruhan jawaban melalui angket ternyata semuanya memenuhi syarat untuk dianalisis. Responden dalam penelitian ini berusia antara 15 tahun hingga 18 tahun, usia tersebut merupakan usia remaja dan menjadi penonton setia televisi terutama tayangan sinetron, yang banyak bertemakan remaja. Jika dilihat frekuensinya, responden yang berusia 15 tahun jumlahnya paling banyak yakni 33 orang $(38,4 \%)$, kemudian yang berusia 16 tahun berjumlah 9 orang $(10,5 \%)$, responden yang berusia 17 tahun berjumlah 32 orang $(37,2 \%)$, dan responden yang berusia 18 tahun berjumlah 12 orang (14\%). Usia 16 tahun hingga 18 tahun termasuk dalam katagori remaja awal, pada masa tersebut mereka masih ingin menemukan jati diri mereka. Sehingga dikhawatirkan akan mudah terpengaruh oleh hal-hal yang kurang sesuai dengan kepribadian atau jati 
diri remaja. Responden yang berjenis kelamin perempuan lebih banyak yakni 70 orang $(81,4 \%)$ dibanding dengan responden yang berjenis kelamin laki-laki 16 orang $(18,6 \%)$. Hal ini juga mengindikasikan bahwa tayangan sinetron ternyata lebih banyak disukai oleh remaja yang berjenis kelamin perempuan.

Sementara itu berdasarkan hasil penelitian, tayangan televisi yang paling disukai responden adalah sinetron dan film dengan frekuensi 47 (54,7\%). Tayangan selanjutnya yang paling disukai oleh responden adalah talkshow dengan frekuensi 21 (24,4\%), tayangan infotainment disukai oleh 11 responden $(12,8 \%)$, dan terakhir berita hanya disukai oleh 7 responden $(8,1 \%)$. Televisi sebagai media massa memiliki beberapa fungsi yang antara lain adalah fungsi mendidik, memberi informasi, dan menghibur. Ternyata di antara ketiga fungsi televisi tersebut, fungsi hiburannya lebih menonjol dibandingkan dengan fungsi-fungsi yang lainnya. Hasil penelitian menunjukkan bahwa mencari hiburan merupakan tujuan menonton televisi yang paling banyak dipilih responden. Data secara lengkap terlihat pada tabel 2.

Banyaknya stasiun televisi yang bersiaran di Indonesia baik televisi nasional maupun televisi lokal, membuat masyarakat mempunyai banyak pilihan untuk menonton acara apa saja yang ditayangkan stasiun televisi tersebut. Namun demikian stasiun televisi swasta nasional masih menjadi andalan responden untuk memenuhi kebutuhan mereka akan informasi, pendidikan, dan hiburan. Hal tersebut terbukti dari hasil penelitian,

Tabel 2

Tujuan Responden Menonton Televisi

\begin{tabular}{llcc}
\hline No. & \multicolumn{1}{c}{ Keterangan } & F & $\%$ \\
\hline 1. & Mencari Informasi & 71 & 30,9 \\
2. & Mencari Ilmu & 52 & 22,6 \\
3. & Mencari Hiburan & 102 & 44,3 \\
4. & Ketiganya & 5 & 2,2 \\
\hline & Jumlah : & 230 & 100 \\
\hline
\end{tabular}

Sumber: Hasil Penelitian 2012(Jawaban lebih dari satu)

Tabel 3

Alasan Responden Menonton Acara di Stasiun Televisi tertentu

\begin{tabular}{|c|c|c|c|}
\hline No. & Keterangan & $\mathrm{F}$ & $\%$ \\
\hline 1. & $\begin{array}{l}\text { Karena televisi swasta program acaranya lebih bagus dan bervariasi di banding TVRI atau } \\
\text { Televisi Lokal }\end{array}$ & 56 & 65,1 \\
\hline 2. & Karena televisi swasta lebih banyak menayangkan sinetron dan film lepas & 18 & 20,9 \\
\hline 3. & Karena TVRI dan Televisi Lokal program acara kurang bervariasi & 3 & 3,5 \\
\hline 4. & Karena sinetron-sinetron remaja banyak ditayangkan di televisi swasta & 9 & 10,5 \\
\hline & Jumlah & 86 & 100 \\
\hline
\end{tabular}

Sumber: Hasil Penelitian 2012 
responden yang menonton televisi swasta dan lokal tapi porsi menonton televisi swasta lebih banyak merupakan pilihan terbanyak responden yakni 35 orang (40,7\%), kemudian responden yang selain menonton acara yang ditayangkan di televisi swasta tetapi juga menonton acara dari TVRI namun dengan porsi menonton televisi swasta lebih banyak berjumlah 34 orang $(39,5 \%)$, kemudian responden yang hanya menonton televisi swasta saja sebanyak 10 orang $(11,6 \%)$, yang menonton TVRI, televisi lokal, dan televisi swasta, namun tetap menonton acara di televisi swasta lebih besar porsinya sebanyak 6 orang $(4,7 \%)$, yang hanya menonton televisi lokal saja 2 orang $(2,3 \%)$, dan terakhir responden yang hanya menonton acara di TVRI saja sebanyak satu orang $(1,2 \%)$. Alasan yang dikemukakan oleh responden berkaitan dengan stasiun televisi yang ditonton seperti terlihat pada Tabel 3 . Karena responden dalam penelitian ini adalah pelajar maka kesempatan mereka untuk menonton televisi adalah sore dan malam hari ketika mereka pulang sekolah.

Waktu yang digunakan responden untuk menonton televisi sangat beragam, namun berdasarkan hasil penelitian, sore dan malam hari merupakan waktu yang paling banyak digunakan 39 responden $(45,3 \%)$ untuk menonton televisi. Sore hari sekitar pukul 16.00 WIB hingga 18.00 WIB. Malam hari sekitar pukul 20.00 WIB hingga 22.00 WIB. Waktuwaktu tersebut adalah saat ditayangkannya sinetron maupun film. Sebagai pelajar pagi hingga siang adalah waktu belajar di sekolah sehingga menonton televisi dilakukan pada sore dan malam hari. Sementara waktu yang digunakan responden untuk menonton televisi merupakan jam belajar responden, sehingga penayangan sinetron pada jam-jam tersebut dikhawatirkan mengganggu aktivitas belajar responden.

\section{Analisis Korelasi Variabel Tayangan Sinetron Remaja di Televisi Swasta dengan Sikap mengenai Gaya Hidup Hedonis}

Hasil uji validitas untuk $n=17$, seluruh instrumen pertanyaan yang membentuk variabel pengaruh tayangan sinetron (intensitas menonton, daya tarik penyajian, dan isi pesan) memiliki nilai koefisien validitas $>$ titik kritis $(0,300)$ sehingga seluruh instrumen pertanyaan tersebut dinyatakan valid. Untuk pengujian reliabilitas diperoleh nilai koefisien reliabilitas sebesar 0,877>0,700 dan dinyatakan reliabel. Jadi, dapat disimpulkan, instrumen yang digunakan sudah mampu mengukur apa yang seharusnya di ukur dan layak digunakan dalam penelitian selanjutnya.

Pengujian hipotesis dengan menggunakan analisis Regresi Linear Berganda dilakukan untuk mengetahui seberapa besar pengaruh variabel intensitas menonton tayangan sinetron remaja di televisi swasta (X1), daya tarik tayangan sinetron remaja di televisi swasta (X2), isi pesan tayangan sinetron remaja di televisi swasta (X3) terhadap sikap mengenai gaya hidup hedonis (Y). Persamaan Regresi Linear Berganda yang akan dibentuk adalah sebagai berikut: $\mathrm{Y}=\mathrm{b}_{0}+\mathrm{b}_{1} \mathrm{X}_{1}+$ $\mathrm{b}_{2} \mathrm{X}_{2}+\mathrm{b}_{3} \mathrm{X}_{3}$, di mana $\mathrm{Y}=$ sikap gaya hidup hedonis, $\mathrm{X}_{1}=$ intensitas menonton, $\mathrm{X}_{2}=$ daya tarik, $X_{3}=$ isi pesan tayangan sinetron, $\mathrm{b}_{0}=$ intersept (konstanta), $\mathrm{b}_{1}, \mathrm{~b}_{2}, \mathrm{~b}_{3}=$ koefisien arah regresi. Dengan menggunakan bantuan program SPSS, diperoleh hasil seperti terlihat pada tabel 4 .

Dikarenakan nilai $F_{\text {hitung }}(22,905)>$ $F_{\text {tabel }}(2,716)$ maka $\mathrm{H}_{0}$ ditolak, artinya secara simultan intensitas menonton $\left(\mathrm{X}_{1}\right)$, daya tarik $\left(\mathrm{X}_{2}\right)$ dan isi pesan $\left(\mathrm{X}_{3}\right)$ berpengaruh signifikan terhadap sikap gaya hidup hedonis (Y). Hasil pengujian hipotesis secara parsial (Uji t) seperti terlihat pada Tabel 5 .

Secara simultan tayangan sinetron (intensitas, daya tarik, dan isi pesan) memberikan kontribusi pengaruh sebesar $45,6 \%$ terhadap sikap gaya hidup hedonis, sedangkan sisanya sebanyak 100\%-45,6\% $=54,4 \%$ merupakan kontribusi pengaruh variabel lain yang tidak diteliti.

Hasil penelitian menunjukkan bahwa secara simultan tayangan sinetron memberikan kontribusi pengaruh sebesar 45,6\% terhadap sikap gaya hidup hedonis, untuk melihat pengaruh secara parsial dapat dilihat pada Tabel 6 . 
Tabel 4

Output Pengujian Regresi

\begin{tabular}{|c|c|c|c|c|c|}
\hline \multirow{2}{*}{.Model } & \multicolumn{2}{|c|}{ Unstandardized Coefficients } & \multirow{2}{*}{$\frac{\text { Standardized Coefficients }}{\text { Beta }}$} & \multirow[b]{2}{*}{$\mathrm{t}$} & \multirow[b]{2}{*}{ Sig. } \\
\hline & B & Std.Error & & & \\
\hline 1. (Constant) & 2,775 & 7,093 & & ,391 & ,697 \\
\hline Intensitas Menonton & 687 &, 124 & ,462 & 5,533 &, 000 \\
\hline Tayangan Sinetron (X1) & .505 & 212 & .208 & 2,376 & 020 \\
\hline $\begin{array}{l}\text { Sinetron (X2) } \\
\text { Isi Pesan Tayangan } \\
\text { Sinetron (X3) }\end{array}$ & 695 & 201 & ,298 & 3,458 &, 001 \\
\hline
\end{tabular}

Tabel 5

Uji Hipotesis secara Parsial (Uji t)

\begin{tabular}{|c|c|c|c|c|c|}
\hline No & Hipotesis & t-hitung & t-tabel & $P$-Value & $\begin{array}{l}\text { Kesimpulan } \\
\text { Statistik }\end{array}$ \\
\hline 1 & $\begin{array}{l}\text { Intensitas menonton sinetron berpengaruh } \\
\text { signifikan terhadap sikap gaya hidup hedonis }\end{array}$ & 5,533 & 1,989 & 0,000 & $\begin{array}{r}\text { Signifikan } \\
\left(\mathrm{H}_{0} \text { ditolak }\right)\end{array}$ \\
\hline 2 & $\begin{array}{l}\text { Daya tarik sinetron berpengaruh signifikan } \\
\text { terhadap sikap gaya hidup hedonis }\end{array}$ & 2,376 & 1,989 & 0,020 & $\begin{array}{r}\text { Signifikan } \\
\left(\mathrm{H}_{0} \text { ditolak }\right)\end{array}$ \\
\hline 3 & $\begin{array}{l}\text { Isi pesan sinetron berpengaruh signifikan terhadap } \\
\text { sikap gaya hidup hedonis }\end{array}$ & 3,458 & 1,989 & 0,001 & $\begin{array}{r}\text { Signifikan } \\
\left(\mathrm{H}_{0} \text { ditolak }\right)\end{array}$ \\
\hline
\end{tabular}

Sumber: Hasil Penelitian 2012

Tabel 6

Pengaruh Variabel X secara Parsial Terhadap Variabel Y

\begin{tabular}{|c|c|c|}
\hline No & Pengaruh $\mathrm{X}$ terhadap $\mathrm{Y}$ & Persentase \\
\hline 1 & Pengaruh $\mathrm{X}_{1}$ terhadap $\mathrm{Y}$ & $24,9 \%$ \\
\hline 2 & Pengaruh $\mathrm{X}_{2}$ terhadap $\mathrm{Y}$ & $8,4 \%$ \\
\hline 3 & Pengaruh $\mathrm{X}_{3}$ terhadap $\mathrm{Y}$ & $12,4 \%$ \\
\hline 4 & Total pengaruh variabel X terhadap Y secara simultan & $45,6 \%$ \\
\hline 5 & Pengaruh variabel lain yang tidak diteliti & $54,4 \%$ \\
\hline \multicolumn{2}{|r|}{ Total } & $100 \%$ \\
\hline
\end{tabular}

Sumber: Hasil Penelitian 2012 
Pengaruh Intensitas Menonton, Daya Tarik, dan Isi Pesan Sinetron Remaja di Televisi Swasta terhadap Sikap mengenai Gaya Hidup Hedonis

Tayangan sinetron akhir-akhir ini hampir mendominasi program acara di televisi khususnya televisi swasta. Bahkan tayangan tersebut disiarkan pada jam prime time (antara pukul 18.30 - 21.00 WIB). Tayangan sinetron yang saat ini mendominasi acara di televisi swasta kebanyakan mengangkat tema-tema remaja. Penayangan pada jam-jam primetime tersebut dikhawatirkan akan mengganggu jam belajar penonton yang dipastikan adalah anak-anak dan remaja. Selain itu, tema-tema cerita sinetron remaja saat ini banyak yang kurang memberikan contoh yang baik pada penontonnya, pesan-pesan yang disampaikannya cenderung kurang mendidik, seperti banyaknya adegan-adegan kekerasan, konflik dalam keluarga, gaya hidup hedonis, dan lain-lain.

Pengelola televisi dan pembuat cerita sinetron remaja tampaknya melihat peluang bahwa khususnya sinetron banyak ditonton remaja sehingga mereka berlomba-lomba menyajikan sinetron bertema remaja tanpa mengindahkan mutu atau kualitas ceritanya, pesan-pesan yang disampaikannyapun kurang jelas. Cerita sinetron remaja yang banyak berkiblat pada budaya "Barat" tentunya sangat tidak sesuai dengan budaya orang Indonesia, namun itulah kenyataannya. Cerita-cerita seperti itulah yang saat ini digemari oleh penonton khususnya remaja.

Remaja merupakan masa transisi dari anak-anak ke dewasa. Pada masa ini merupakan masa-masa rawan karena mereka sedang mencari jati dirinya. Pencarian jati diri dapat dimulai dari lingkungan di sekitarnya. Saat ini tampaknya televisi sudah merupakan bagian dari kehidupan manusia tidak terkecuali remaja. Dengan berbagai program acara yang dikemas secara menarik membuat penontonnya betah berlama-lama di depan televisi dan menjadi bagian tak terpisahkan dengan mereka.

Hasil pengujian terhadap ketiga hipotesis penelitian, yaitu pengaruh intensitas menonton tayangan sinetron remaja di televisi swasta terhadap sikap mengenai gaya hidup hedonis, pengaruh daya tarik sinetron remaja di televisi swasta terhadap sikap mengenai gaya hidup hedonis, pengaruh isi sinetron remaja di televisi swasta terhadap sikap mengenai gaya hidup hedonis, mengisyaratkan bahwa hipotesis penelitian tersebut teruji. Terujinya hipotesis penelitian memberikan arti bahwa intensitas, daya tarik, dan isi pesan dalam tayangan sinetron remaja di televisi swasta berpengaruh secara signifikan terhadap sikap mengenai gaya hidup hedonis remaja. Total pengaruhnya sebesar $45,6 \%$, sementara itu $54,4 \%$ sikap mengenai gaya hidup hedonis dipengaruhi oleh variabel lain yang tidak diteliti.

Mengacu pada konsep yang dikemukakan Bandura dalam Teori Belajar Sosial, yang menjadi pijakan dalam penelitian ini, ternyata sikap remaja terhadap gaya hidup hedonis sebagian dipengaruhi oleh cara belajar individu melalui televisi yang dilakukan melalui peniruan para pemain dalam sinetron remaja. Menurut Bandura bahwa kita belajar bukan saja dari pengalaman langsung, tetapi dari peniruan atau peneladanan (modeling). Perilaku merupakan faktor-faktor kognitif dan lingkungan. Artinya kita mampu memiliki keterampilan tertentu, bila terdapat jalinan positif antara stimuli yang kita amati dan karakteristik diri kita (Rakhmat, 1998).

Media televisi dengan berbagai kelebihan yang dimilikinya seperti sifatnya yang audio visual yakni dapat memadukan suara dan gambar yang bergerak. Televisi berkat perkembangan teknologi juga mampu menayangkan gambar atau benda yang tidak dapat dilihat dengan mata telanjang, sebagai contoh kamera televisi mampu menangkap gambar dalam kegelapan dengan inteosifler. Dengan kelebihan-kelebihan yang dimilikinya inilah televisi dapat memengaruhi penonton terutama dalam membentuk dan mengubah sikap penontonnya. Seperti apa yang dikatakan Khadiz dalam Mulyana (1997), bahwa televisi melalui sajiannya yang menarik mengakibatkan penonton seringkali terpaku dan hanyut dalam dramatisasi acara. Dalam posisi inilah kesadaran pemirsa 
seolah-olah terhipnosis oleh sugesti daya pikat televisi, sebagai akibatnya televisi akan berpengaruh pada sikap, pandangan, persepsi, sampai pada perilaku pemirsanya (Rinawati, 2002). Hasil penelitian ini juga sesuai dengan apa yang dikatakan oleh Mar'at bahwa acara televisi pada umumnya memengaruhi sikap, pandangan, persepsi, dan perasaan penonton (Effendy, 1986).

Ada hal lain yang muncul akibat globalisasi informasi dan komunikasi, khususnya yang menggunakan media televisi ini. Efek sosial yang bisa memuat unsur-unsur perubahan nilai sosial dan budaya dalam masyarakat bisa juga terjadi akibat masyarakat pemirsa media televisi ini meng"iya"kan setiap nilai baru yang ditawarkan media televisi. Manusia cenderung menjadi konsumen budaya massa yang aktif. Hal ini mengakibatkan pola-pola kehidupan rutinitas manusia sebelum muncul televisi menjadi berubah, bahkan secara total. Televisi menjadi anutan baru (new religion) buat masyarakat (Istiyanto, 2008).

\section{Pengaruh Intensitas Menonton Tayangan Sinetron Remaja di Televisi Swasta terhadap Sikap mengenai Gaya Hidup Hedonis}

Berdasarkan hasil pengujian terhadap hipotesis pertama yakni intensitas menonton tayangan sinetron remaja di televisi swasta terhadap sikap mengenai gaya hidup hedonis, mengisyaratkan bahwa hipotesis penelitian teruji. Intensitas menonton tayangan sinetron remaja memberikan kontribusi pengaruh terhadap sikap mengenai gaya hidup hedonis dengan kontribusi pengaruh yang diberikan sebesar 24,9\%.

Menurut Danim (1995), intensitas menonton televisi dapat diartikan tingkat keseringan menonton siaran yang ditayangkan dalam televisi dengan tingkat perhatian tertentu. Gomstock mengatakan bahwa televisi telah menjadi faktor yang tak terelakkan dan tak terpisahkan dalam membentuk diri kita dan akan seperti apa diri kita nanti (Vivian, 2008). Dengan semakin seringnya waktu yang digunakan menonton televisi, maka akan semakin kuat pula pengaruh yang diberikan televisi terhadap mereka. Seperti apa yang dikatakan oleh Neumann dalam Vivian (2008) bahwa media tidak punya efek langsung yang kuat, tetapi efek itu akan terus menguat seiring dengan berjalannya waktu.

Hasil penelitian menunjukkan bahwa intensitas menonton tayangan sinetron remaja di televisi dilihat dari frekuensinya maupun durasinya cukup tinggi. Sekali menonton tayangan sinetron mereka bisa menghabiskan waktu hingga 4 jam dalam sehari. Dwyer dalam Anwas (2008) mengatakan bahwa televisi sebagai media audio visual mampu merebut 94\% saluran masuknya pesan-pesan atau informasi ke dalam jiwa manusia yaitu lewat mata dan telinga. Televisi mampu membuat orang pada umumnya mengingat $50 \%$ dari apa yang mereka lihat dan dengar di layar televisi walaupun hanya sekali ditayangkan. Atau secara umum orang akan ingat $85 \%$ dari apa yang mereka lihat di televisi setelah tiga jam kemudian dan $65 \%$ setelah tiga hari kemudian. Hal ini menunjukkan pengaruh yang dihasilkan dari menonton televisi sangat besar. Hal ini disebabkan oleh intensitas menonton seseorang, informasi yang diserap secara terus menerus akan menimbulkan kesan menyenangkan dan akan sanggup menarik perhatian seseorang. Seperti yang dikatakan Bandura, melalui proses perhatian, pengingatan, reproduksi motoris, dan motivasional, seseorang akan meniru atau meneladani apa yang dilihatnya di televisi, dalam hal ini adalah tayangan sinetron remaja di televisi.

\section{Pengaruh Daya Tarik Tayangan Sinetron Remaja di Televisi Swasta terhadap Sikap mengenai Gaya Hidup Hedonis}

Berdasarkan hasil pengujian terhadap hipotesis kedua yakni pengaruh daya tarik tayangan sinetron remaja di televisi swasta terhadap sikap mengenai gaya hidup hedonis, mengisyaratkan bahwa hipotesis penelitian teruji. Daya tarik tayangan sinetron remaja memberikan kontribusi pengaruh terhadap sikap mengenai gaya hidup hedonis dengan kontribusi pengaruh yang diberikan sebesar 
$8,4 \%$. Daya tarik tayangan sinetron remaja ternyata tidak memberikan pengaruh yang cukup besar terhadap sikap mengenai gaya hidup hedonis. Meskipun demikian, tayangan tersebut memberikan pengaruh yang kurang baik pada penontonnya. Tema sinetron yang kebanyakan menyajikan cerita kehidupan yang glamor dan penuh kemewahan, tanpa melakukan kerja keras seseorang dapat hidup enak, mewah, bersenang-senang, dapat menimbulkan fantasi dalam diri penontonnya.

Teori Belajar Sosial dari Bandura menyebutkan bahwa seseorang akan meneladani apa yang dilihatnya di televisi, termasuk gaya hidup yang ditampilkan dalam sinetron tersebut, meskipun pengaruhnya kecil, karena memang gaya hidup hedonis tidak semuanya dipengaruhi dari tayangan sinetron di televisi saja.

\section{Pengaruh Isi Pesan Tayangan Sinetron Remaja di Televisi Swasta terhadap Sikap mengenai Gaya Hidup Hedonis}

Perkembangan sinetron di Indonesia saat ini begitu pesat seiring dengan perkembangan stasiun televisi. Jika diamati tayangan-tayangan sinetron remaja di televisi yang mengangkat tema-tema gaya hidup hedonis, memperlihatkan perilaku hidup mewah dan bersenang-senang dari para pemainnya. Pesan-pesan yang ingin disampaikannya tidak jelas. Namun demikian banyak penonton yang menyukainya. Hal tersebut dikhawatirkan akan memengaruhi sikap dan perilaku penontonnya, yakni membentuk masyarakat khususnya remaja menjadi pribadi yang konsumtif dan hedonis.

Semua peristiwa komunikasi yang dilakukan mempunyai tujuan yakni memengaruhi khalayak. Sinetron merupakan salah satu bantuk aktualitas komunikasi dan interaksi manusia yang diolah berdasarkan alur cerita yang mengangkat kehidupan sehari-hari masyarakat. Namun dalam perkembangannnya, isi sinetron banyak yang tidak berkiblat pada budaya dan adat istiadat masyarakat Indonesia. Ceritanya banyak mengangkat pergaulan remaja masa kini, yang dianggap modern, seperti berpacaran di sekolah.
Berdasarkan teori Belajar Sosial dari Bandura, khalayak akan belajar dari apa yang dilihatnya yang salah satunya adalah tayangan sinetron di televisi.

Berdasarkan hasil pengujian terhadap hipotesis ketiga yakni pengaruh isi pesan tayangan sinetron remaja di televisi swasta terhadap sikap mengenai gaya hidup hedonis, mengisyaratkan bahwa hipotesis penelitian teruji. Isi pesan tayangan sinetron remaja memberikan kontribusi pengaruh terhadap sikap mengenai gaya hidup hedonis dengan kontribusi pengaruh yang diberikan sebesar $12,4 \%$.

\section{PENUTUP}

\section{Simpulan}

Intensitas menonton sinetron di televisi swasta berpengaruh secara signifikan terhadap sikap mengenai gaya hidup hedonis di Cimahi. Intensitas tersebut ditunjukkan dengan frekuensi dan durasi menonton sinetron remaja di televisi swasta.

Daya tarik sinetron remaja di televisi swasta berpengaruh secara signifikan terhadap sikap mengenai gaya hidup hedonis di Cimahi. Daya tarik tersebut ditunjukkan dengan tema-tema cerita sinetron remaja yang ditayangkan di televisi swasta, karena tematema tersebut sedikit banyak sesuai dengan jiwa responden sebagai seorang remaja.

Isi pesan sinetron remaja di televisi swasta berpengaruh secara signifikan terhadap sikap mengenai gaya hidup hedonis di Cimahi.

Intensitas menonton sinetron remaja, daya tarik sinetron remaja, isi pesan sinetron remaja di televisi swasta secara bersama-sama berpengaruh secara signifikan terhadap sikap mengenai gaya hidup hedonis di Cimahi. Dari ketiga dimensi tersebut intensitas menonton sinetron remaja di televisi swasta memberikan kontribusi paling besar pengaruhnya dibandingkan dengan daya tarik sinetron remaja dan isi pesan sinetron remaja di televisi swasta. 
Saran

Para pengelola televisi khususnya televisi swasta hendaknya mulai memilah dan memilih sinetron yang hendak ditayangkan, karena bagaimanapun tayangan tersebut akan memberikan pengaruh pada penontonnya, terutama penonton yang masih berusia remaja. Tema-tema sinetron maupun isinya yang hendak ditayangkan sebaiknya disaring terlebih dahulu agar tayangan sinetron yang akan disiarkan sesuai dengan karakter dan budaya Indonesia.

Komisi Penyiaran Indonesia (KPI) sebagai lembaga yang mengawasi isi maupun program-program televisi khususnya televisi swasta hendaknya lebih ketat dalam mengawasi acara-acara yang ditayangkan di televisi khususnya tayangan sinetron yang saat ini begitu banyak jumlahnya di televisi swasta. Karena banyak sinetron televisi yang isinya kurang memberikan pendidikan kepada masyarakat khususnya remaja.

\section{DAFTAR PUSTAKA}

\section{Buku :}

Archie, Brahm. (2003). Filsafat Perbandingan. Yogyakarta: Kanisius.

Arikunto, Suharsimi.(1998).Prosedur Penelitian Suatu Pendekatan Praktik.Jakarta:Rineka Cipta.

Effendy, Onong Uchjana. (1986). DimensiDimensi Komunikasi. Bandung: Alumni.

(2003). Komunikasi dalam Teori dan Praktek. Bandung: Remaja Rosdakarya.

Kriyantono, Rahmat.(2006). Teknis Praktis Riset Komunikasi. Jakarta: Prenada Media Group.

Morissan. (2009). Manajemen Media Penyiaran, Strategi Mengelola Radio\&Televisi. Cetakan ke-2. Jakarta: Kencana Prenada Media Group.

Rakhmat, Jalaluddin. (1998). Psikologi Komunikasi. Bandung: Remaja Rosdakarya.

Metode Penelitian Komunikasi.
Remaja Rosdakarya.

Saifuddin, Azwar. (1995). Sikap Manusia: Teori dan Pengukurannya. Yogyakarta: Pustaka Pelajar.

(1997). Reliabilitas dan Validitas. Yogyakarta: Pustaka Pelajar.

Severin, Werner J dan James W.Tankard, Jr. (2002). Teori Komunikasi Sejarah, Metode, dan Terapan di dalam Media Massa. Edisi ke2. Jakarta: Kencana Prenada Medai Group.

Singarimbun, Masri.1989. Metode Penelitian Survey. Jakarta: PT Midas Surya Grafindo.

Tan, Alexis S. (1981). Mass Communication Theories and Research. Columbus Ohio: Grid Publishing, inc.

Vivian, John. (2008). Teori Komunikasi Massa edisi kedelapan. Jakarta: Kencana Prenada Media Group.

\section{Sumber lainnya:}

\section{Jurnal :}

Rinawati, Rini. (2002) Pengaruh Sinetron Terhadap Sikap Ibu-Ibu Mengenai Peran Ganda Wanita. MediatorJurnal Komunikasi, Volume 3. No. 1, hal.110.

\section{Internet :}

Anonim.(2011).Sinetron.Tersedia dalam $<$ http://digilib.petra.ac.id/viewer.php?>. Diakses tanggal 29 Januari 2013.

Dyah, Purplenita.(2012). Tersedia dalam $<$ http://purplenitadyah.wordpress.com/2 012/05/05/hedonisme/> diakses tanggal 13 April 2013.

Falanta, Evelin.(2011).Duh, ternyata jumlah penonton sinetron di kuartal I 2011 naik 55\%. Tersedia dalam $<$ http://industri.kontan.co.id/news/duhternyata-jumlah-penonton-sinetron-dikuartal-i-2011-naik-55-1>. Diakses tanggal 30 Januari 2013.

Munandar, Imam.(2012). Hedonisme. Tersedia dalam $<$ http://ipsb2011.wordpress.com/2012/0 6/10/hedonisme/>.Diakses tanggal 13 April 2013.

Yagami,Wing.(2011).Sinetron sebagai Media Massa, Perkembangan serta 
Pengaruhnya. Tersedia

dalam

$<$ http://www.winkplace.com/2011/03/si

netron-sebagai-media-massa.html $>$.

Diakses tanggal 3 Februari 2013. 